\title{
A Brief Essay on the Use of Antidepressants for Cocaine Dependence
}

\author{
Iri Sandro Pampolha Lima and Jucier Gonçalves Júnior* \\ School of Medicine, Federal University of Cariri (UFCA), Barbalha, Brazil
}

Submission: July 03, 2016; Published: July 19, 2017

*Corresponding author: Jucier Gonçalves Júnior, School of Medicine, Federal University of Cariri (UFCA), Barbalha, Divine Savior Street, Downtown, Barbalha, Ceará, Brazil, Tel: +055(88) 3312-5003; E-mail: juciergjunior@hotmail.com

\section{Mini Review}

Cocaine addiction is a chronic, progressive, relapsing disease, in which medical, psychiatric and social deteriorations occur. The mechanism of action of cocaine involves inhibition of neuronal monoamine transporters, in some brain structures and primarily in the dopamine reuptake system located in mesolimbic neurons. Cocaine rapidly increases the dopaminergic neurotransmission, and triggers adaptive changes in circuits underlying reinforcement, reward, sensitization and the high addictive potential of cocaine [1].

Some works have attempted to link molecular aspects of neural mechanisms, underlying the behavioral effects of repeated drug administration, and those responsible for traditional forms of learning and memory [2]. Increases in dopamine (DA) have been shown to be associated with reports of drug reinforcement, corroborating the relevance of drug-induced DA increases in the rewarding effects of drugs in humans [3]. Drugs of abuse are known to cause persistent modifications of neural circuits, leading to addictive behaviors and changes in synaptic plasticity, in dopaminergic neurons of the ventral tegmental area (VTA). These alterations may contribute to circuit modification, induced by many drugs of abuse, including cocaine [4]. This cocaineinduced enhancement of synaptic plasticity in the VTA may be important for the formation of drug-associated memory.

Despite the great number of studies on cognitive deficits in cocaine abusers, the nature of these deficits is still uncertain [5]. Evidences [6] indicated that, in relation to other psychopathological disorders, the severity of neuropsychological impairments in cocaine addiction is modest, albeit not indicative of the absence of neurocognitive dysfunctions. According to these authors, the impact of such small differences in performance on the quality of life, as well as on craving and relapse, may be substantial.

Cocaine addiction continues to be a worldwide important public health problem; and, although there is no approved pharmacotherapy for cocaine addiction, a number of drugs have been tested with some promising results [7]. In the short term, cocaine appears to stimulate dopaminergic neurotransmission, by blocking the reuptake of dopamine. However, evidence suggests that, with long-term use, the nerve terminals may be depleted of dopamine. Dopamine depletion has been thought to contribute to the dysphoria that develops during withdrawal from cocaine and the subsequent craving for more of the drug. In this way, alterations in dopamine neurotransmission may be responsible for the development of compulsive use patterns. With higher doses and regular use, other neurotransmitter systems such as serotonin are probably directly or indirectly mediating CNS toxicity [8].

Initial studies of pharmacological treatments for cocaine dependence focused largely on drugs that would directly influence the dopaminergic function, but most of these agents have been found to be ineffective [9]. Despite advances and promising findings from preclinical research, no approved pharmacological treatment exists for cocaine abuse [10]. There is evidence [11] indicating that chronic, heavy cocaine abusers have persistent deficits in neurobehavioral functioning. Antidepressants may be used for the symptons withdrawal of chronic cocaine abuse, because one of its actions is to block the reuptake of catecholamines and stabilize their receptors [12].

In common with all other classes of substance-abuse disorders, cocaine dependence has been shown by community and clinical surveys to be strongly associated with depression [13]. Cocaine abuse may lead to overdose (related to seizures and/or status epilepticus) and to diseases (schizophrenia, depression and anxiety) [14]. Antidepressants are commonly used in substance abusers, due to their potential effect on some underlying mechanisms involved in drug-use disorders, and in the treatment of comorbid depression, although more studies are necessary to be conclusive. Interestingly, SSRIs do not seem to offer significant advantages, as compared to tricyclic drugs, 
in substance-abuse disorders [15]. It has been recently reported [16] that desipramine, a tricyclic antidepressant, was an effective treatment for depression, among cocaine-dependent patients.

\section{Conclusion}

In the blockade of some effects of cocaine by imipramine is an important issue. However, the implication for the use of antidepressants in the treatment of cocaine addiction is still a question of debate, and deserves further studies.

\section{Acknowledgement}

We are grateful to the Conselho Nacional de Desenvolvimento Científico e Tecnológico (CNPq) and School of Medicine, Federal University of Cariri (UFCA).

\section{Ethical Standards}

The authors assert that all procedures contributing to this work comply with the ethical standards of the relevant national and institutional guides.

\section{References}

1. Maurice T, Martin-Fardon, Romieu PP, Matsumoto RR (2002) Sigma (1) receptor antagonists represent a new strategy against cocaine addiction and toxicity. Neurosci Biobehav Rev 26(4): 499-527.

2. Miller CA, Marshall JF (2005) Molecular substrates for retrieval and reconsolidation of cocaine associated contextual memory. Neuron 47(6): 873-884

3. Volkow ND, Fowler JS, Wang GJ (2002) Role of dopamine reinforcement and addiction in humans: results from imaging studies. Behav Pharmacol 13(5-6): 355-366.

4. Liu QS, Pu L, Poo MM (2005) Repeated cocaine exposure in vivo facilitates LTP induction in midbrain dopamine neurons. Nature 437(7061): 1027-1031.
5. Rogers RD, Robbins TW (2001) Investigating the neurocognitive deficits associated with chronic drug misuse. Curr Opin Neurobiol 11(12): 250-257.

6. Goldstein RZ, Leskovian AC, Hoff AL, Hitzemann R, Bashan F, et al. (2004) Severity of neuropsychological impairment in cocaine and alcohol addiction in association with metabolism in the prefrontal cortex. Neuropsychologia 42(11): 1447-1458.

7. Sofuoglu M, Kosten TR (2005) Novel approaches to the treatment of cocaine addiction. CNS Drugs 19(1): 13-25.

8. Cregler LL (1989) Adverse health consequences of cocaine abuse. J Natl Med Assoc 81: 27-38.

9. Lima MS, Oliveira Soares BG, Reisser AA, Farrell M (2002) Pharmacological treatment of cocaine dependence: a systematic review. Addiction 97(8): 931-949.

10. Preti A (2000) Vanoxerine National Institute on drug abuse. Curr Opin Investg Drugs 1: 241-251.

11. Bolla KI, Rothman R, Cadet JL (1999) Neurobehavioral effects of chronic cocaine use. J Neuropsychiatry Clin Neurosci 11(3): 361-369.

12. Taylor WA, Gold MS (1990) Pharmacological approaches to the treatment of cocaine dependence. West J Med 152(2): 573-577.

13. Rounsaville BJ (2004) Treatment of cocaine dependence and depression. Biol Psychiatry 56(10): 803-809.

14. Macedo DS, Santos RS, Belchior LD, Neto MA, Vasconcelos SM, et al. (2004) Effect of anxiolytic, antidepressant and antipsychotic drugs on cocaine-induced seizures and mortality. Epilepsy Behav 5(6): 852-856.

15. Torrens M, Fonseca F, Mateu G, Farre M (2005) Efficacy of antidepressants in substance use disorders with and without comorbid depression: a systematic review and meta-analysis. Drug Alcohol Depend 78(1): 1-22.

16. McDowell D, Nunes EV, Seracini AM, Rothenberg J, Vosburg SK, et al. (2005) Desipramine treatment of cocaine-dependent patients with depression: a placebo-controlled trial. Drug Alcohol Depend 80(2): 209-221.

\section{Your next submission with Juniper Publishers will reach you the below assets}

- Quality Editorial service

- Swift Peer Review

- Reprints availability

- E-prints Service

- Manuscript Podcast for convenient understanding

- Global attainment for your research

- Manuscript accessibility in different formats ( Pdf, E-pub, Full Text, Audio)

- Unceasing customer service

Track the below URL for one-step submission https://juniperpublishers.com/online-submission.php 